\title{
MOHYLOVÁ POHŘEBIŠTĚ STARŠÍ A STŘEDNÍ DOBY BRONZOVÉ V JIŽNIÍCH ČECHÁCH
}

\author{
Kontinuita nebo diskontinuita využívání pohřebních areálů?
}

\author{
O N D Ř J C H V O K A - PETR M E N ŠÍK
}

\begin{abstract}
Early and Middle Bronze Age Burial Mounds in Southern Bohemia. Continuity or Discontinuity of Using Burial Sites? Burial mounds are considered as a typical monument of the Early and Middle Bronze Age in southern Bohemia, representing the only form of graves within BA-BC2 in the area. Although the existing literature has stated hundreds of burial mounds at dozens of cemeteries, after a critical review, only 19 burial mounds from 10 sites can be assigned to the Early Bronze Age, and further 73 burial mounds from 29 sites represent the Middle Bronze Age. Most of the mounds are polycultural, however, burying attributable to both the monitored periods can be unequivocally proven only within four mounds. Even so, an occasional continuity can be taken into account when thinking about using these funeral places.
\end{abstract}

Keywords: South Bohemia, Early Bronze Age, Middle Bronze Age, burial mound cemeteries, burial rite.

\section{ÚVOD}

Mezi nejtypičtější pravěké památky jižních Čech patří bezesporu mohylová pohřebiště, která jsou v tomto regionu díky menšímu rozsahu zemědělsky obdělávané půdy a většímu zalesnění zdejší krajiny relativně dobře dochovaná (srov. např. Beneš/Michálek/Zavřel 1999; Choojka/Krištuf/Rytír 2009; Menšík/ KrištuflChrojka 2010; Michálek 2017; Tisucká 2008, 15). Mohylníky představují pozůstatky dávné kulturní krajiny, zároveň nám ovšem také dokládají mnohdy dlouhodobou kontinuitu využívání těchto funerálních areálů, někdy již od počátku doby bronzové až do časně laténského období, př́ípadně až do raného středověku. V našem příspěvku se budeme zabývat dvěma nejstaršími epochami, v nichž byly v jižních Čechách mohyly budovány, tj. starší a střední dobou bronzovou. Zaměříme se přitom na porovnání pohřebního ritu a na otázku vzájemného vztahu mohylníků z těchto dvou epoch.

Základem předloženého př́spěvku je kritická revize všech jihočeských mohylových hrobů starší a střední doby bronzové. Do následné analýzy jsme zahrnuli pouze prokázané pohřby $\mathrm{z}$ obou uvedených epoch (tabela 1) - soubory artefaktů bez jisté vazby na prokázané pohřby jsme vyloučili, stejně jako nálezy bez jasných nálezových okolností. Neznamená to, že zde nereflektované nálezy nemusejí pocházet $\mathrm{z}$ pohřebních komponent sledovaných epoch, do skupiny jistých mohylových hrobů jsme je však v našem příspěvku nezapočítali.

\section{AKTUÁLNÍ STAV POZNÁNÍ MOHYL STARŠÍ A STŘEDNÍ DOBY BRONZOVÉ V JIŽNÍCH ČECHÁCH}

Z několika stovek dnes $v$ jižních Čechách evidovaných mohylových pohřebišst' (přehledy viz Beneš) Michálek/Zavřel 1999; Fröhlich/Michálek 1978; Chvojkal Krištuf/Rytír 2009; Menšík/Krištuf/Choojka 2010; Michálek 2017; Michálek/Fröhlich 1979; 1987; Michálek/ Zavřel 1996; Tisucká 2008) lze do starší a střední doby bronzové bezpečně zařadit jen jejich malou část. Na pouhých 36 lokalitách byly po kritické revizi bezpečně prokázány pohřby z jednoho nebo obou uvedených období.

Nejstarší datované mohyly spadají v jižních Čechách do starší doby bronzové (Hájek 1954, 122-140; Havlice 2001; Militký 1998), kdy zároveň dochází k stabilnímu osídlení tohoto regionu po dlouhém hiátu v mladém eneolitu. Právě pohřbívání do mohyl, což je zde dosud jediná forma hrobu starší doby bronzové, vedlo L. Hájka k vyčlenění specifickéjihočeské kulturní skupiny (Hájek 1954, 179-182). V současné době je v jižních Čechách známých 37 pohřebišt๋ datovatelných do starší či do přelomu starší a střední doby bronzové (Chvojka/Menšík, v tisku), avšak pouze na deseti lokalitách byly bezpečně doloženy vlastní pohřby (obr. 1). Další mohylníky poskytly pouze artefakty bez prokázaných pohřbů nebo se jedná o lokality s nejasnými nálezovými okolnostmi.

Celkovou strukturu pohřebišt starší doby bronzové nelze přesně postihnout, protože žádný mo- 
Tabela 1. Přehled jihočeských mohylových pohřebišt’ s bezpečně prokázanými pohřby ze starší a střední doby bronzové; mohyly bez publikovaných pohřbů, pouze s dochovanými artefakty, nejsou uvedeny (podkladové zdroje: Dubský 1949; Hájek 1954; Chvojka/Krištuf/Rytír 2009; Chvojka/Michálek 2011; Menšík/Krištuf/Chvojka 2010; Michálek 2017; Militký 1998; Píč 1900; Tisucká 2008 a nepublikované zdroje autorů). * Minimální počet jistých mohyl na lokalitě bez ohledu na jejich dataci, stav prozkoumání a pod.

\begin{tabular}{|c|c|c|c|c|c|c|c|c|}
\hline & Lokalita & Okr. & $\begin{array}{l}\text { Mohyl } \\
\text { celkem* }\end{array}$ & $\begin{array}{c}\text { Mohyly } \\
\text { BA-BA2/ } \\
\text { BB1 }\end{array}$ & $\begin{array}{l}\text { Mohyly } \\
\text { BB-BC }\end{array}$ & $\begin{array}{l}\text { Pohřeb } \\
\text { kostrový }\end{array}$ & $\begin{array}{l}\text { Pohřeb } \\
\text { žárový }\end{array}$ & $\begin{array}{l}\text { Pohřeb } \\
\text { neurčen }\end{array}$ \\
\hline 1 & Albrechtice n. VIt.-Kopanina & $\mathrm{PI}$ & 15 & - & 1 & - & 1 & - \\
\hline 2 & Albrechtice n. Vlt.-V kopcích & $\mathrm{PI}$ & 15 & - & 1 & - & - & 1 \\
\hline 3 & Bernartice & $\mathrm{PI}$ & 5 & - & 1 & - & 1 & - \\
\hline 4 & Čichtice & ST & 65 & - & 2 & - & 2 & - \\
\hline 5 & Dobešice-Slavná hora & $\mathrm{PI}$ & 10 & - & 1 & - & 1 & - \\
\hline 6 & Dobešice-Kolomazná & $\mathrm{PI}$ & 1 & - & 1 & 2 & 1 & - \\
\hline 7 & Dobešice-Hrůbata & $\mathrm{PI}$ & 15 & 1 & 2 & 1 & 2 & - \\
\hline 8 & Dobronice & TA & 30 & - & 4 & - & 2 & 2 \\
\hline 9 & Dražíč & ČB & 37 & - & 1 & - & - & 1 \\
\hline 10 & $\begin{array}{l}\text { Hluboká n. VIt.-Nad } \\
\text { kaštankou }\end{array}$ & С̆В & 35 & 1 & - & 1 & - & - \\
\hline 11 & Hluboká n. Vlt.-Tolomy & С̌B & 19 & - & 1 & - & 1 & - \\
\hline 12 & Hosty & ČB & 78 & 1 & 2 & 1 & - & 4 \\
\hline 13 & Hvožd'any & TA & 98 & - & 11 & 1 & 7 & 4 \\
\hline 14 & Kostelec & С̌B & 28 & - & 3 & - & 2 & 1 \\
\hline 15 & Krašovice & $\mathrm{PI}$ & 1 & - & 1 & - & 1 & - \\
\hline 16 & Křtěnov & ČB & 96 & $1+x$ & $1+x$ & 1 & - & $1+x$ \\
\hline 17 & Kučeř & $\mathrm{PI}$ & 8 & - & 1 & - & 1 & - \\
\hline 18 & Maršov & TA & 1 & 1 & - & - & - & 1 \\
\hline 19 & Nedabyle & С̌B & 13 & 2 & - & 1 & - & 1 \\
\hline 20 & Oldřichov & $\mathrm{PI}$ & 9 & - & 5 & - & 2 & 3 \\
\hline 21 & Paseky & $\mathrm{PI}$ & 7 & 1 & 1 & - & 1 & 2 \\
\hline 22 & Písek & $\mathrm{PI}$ & 2 & - & 2 & - & - & 2 \\
\hline 23 & Plav & С̌B & 35 & - & $3+x$ & 5 & 1 & - \\
\hline 24 & Protivín & $\mathrm{PI}$ & 15 & 3 & - & 1 & $1 ?$ & 1 \\
\hline 25 & Radošovice & ČB & 3 & - & 1 & 1 & - & - \\
\hline 26 & Řepeč & TA & 42 & - & 13 & - & 9 & 5 \\
\hline 27 & Sepekov & $\mathrm{PI}$ & 65 & - & 7 & 2 & 11 & - \\
\hline 28 & Staré Sedlo & TA & 20 & - & 2 & 1 & 1 & - \\
\hline 29 & Těšínov-Sýkovka & $\mathrm{PI}$ & 22 & 1 & - & 1 & $1 ?$ & 2 \\
\hline 30 & Těšínov-Selská & $\mathrm{PI}$ & 64 & 1 & - & - & - & 1 \\
\hline 31 & Topělec & $\mathrm{PI}$ & 42 & - & 1 & - & 1 & - \\
\hline 32 & Týn nad Vltavou & С̌B & 33 & - & 1 & 2 & 2 & - \\
\hline 33 & Údraž & $\mathrm{PI}$ & 30 & - & 1 & - & 1 & - \\
\hline 34 & Újezd u Vodňan & ST & 12 & - & 1 & - & 1 & - \\
\hline 35 & Vodňany & ST & 6 & 6 & - & - & - & 6 \\
\hline 36 & Zběšice & $\mathrm{PI}$ & 43 & - & 1 & - & 2 & - \\
\hline \multicolumn{3}{|l|}{ Celkem } & 1020 & $19+x$ & $73+x$ & 21 & 56 & $38+x$ \\
\hline
\end{tabular}




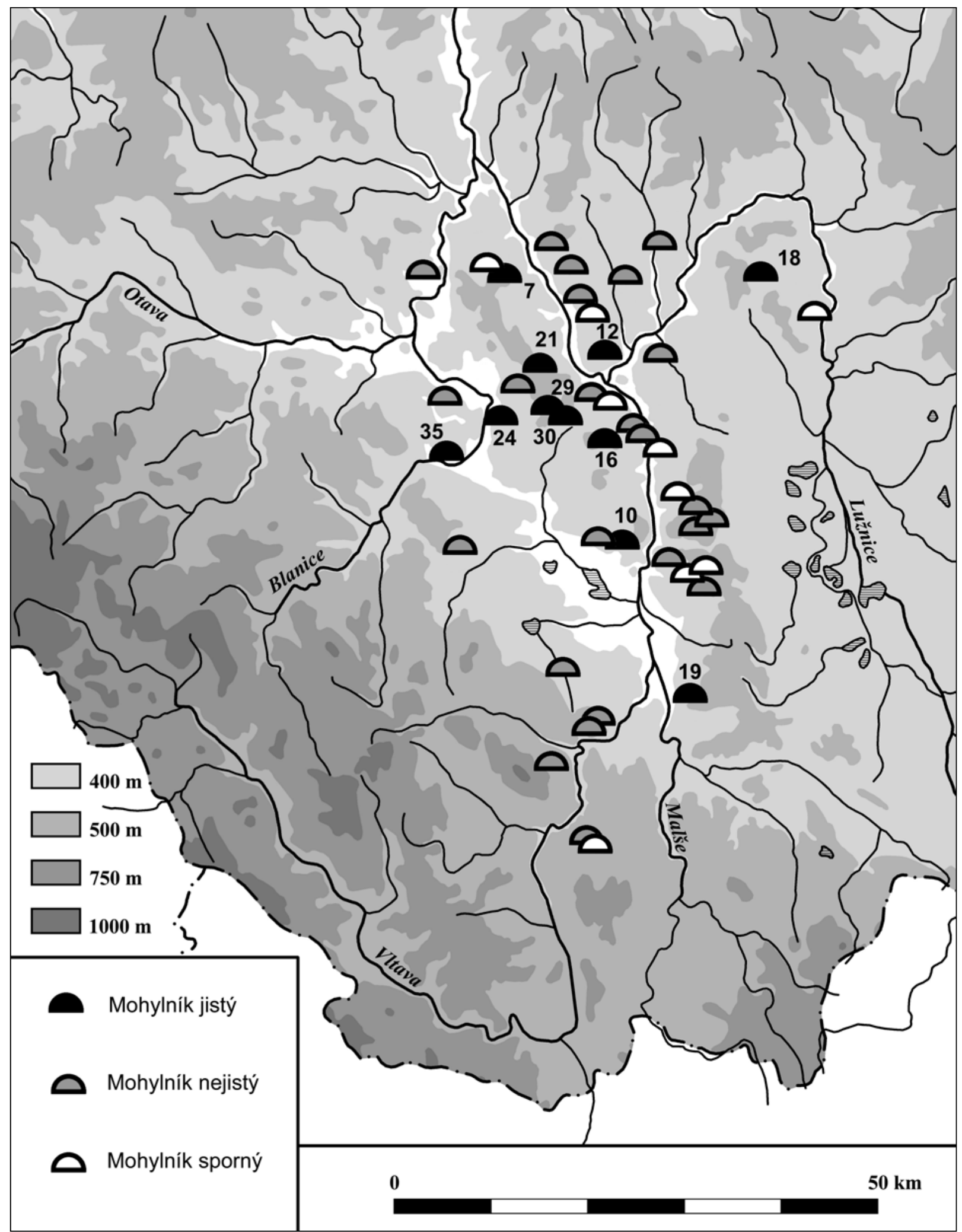




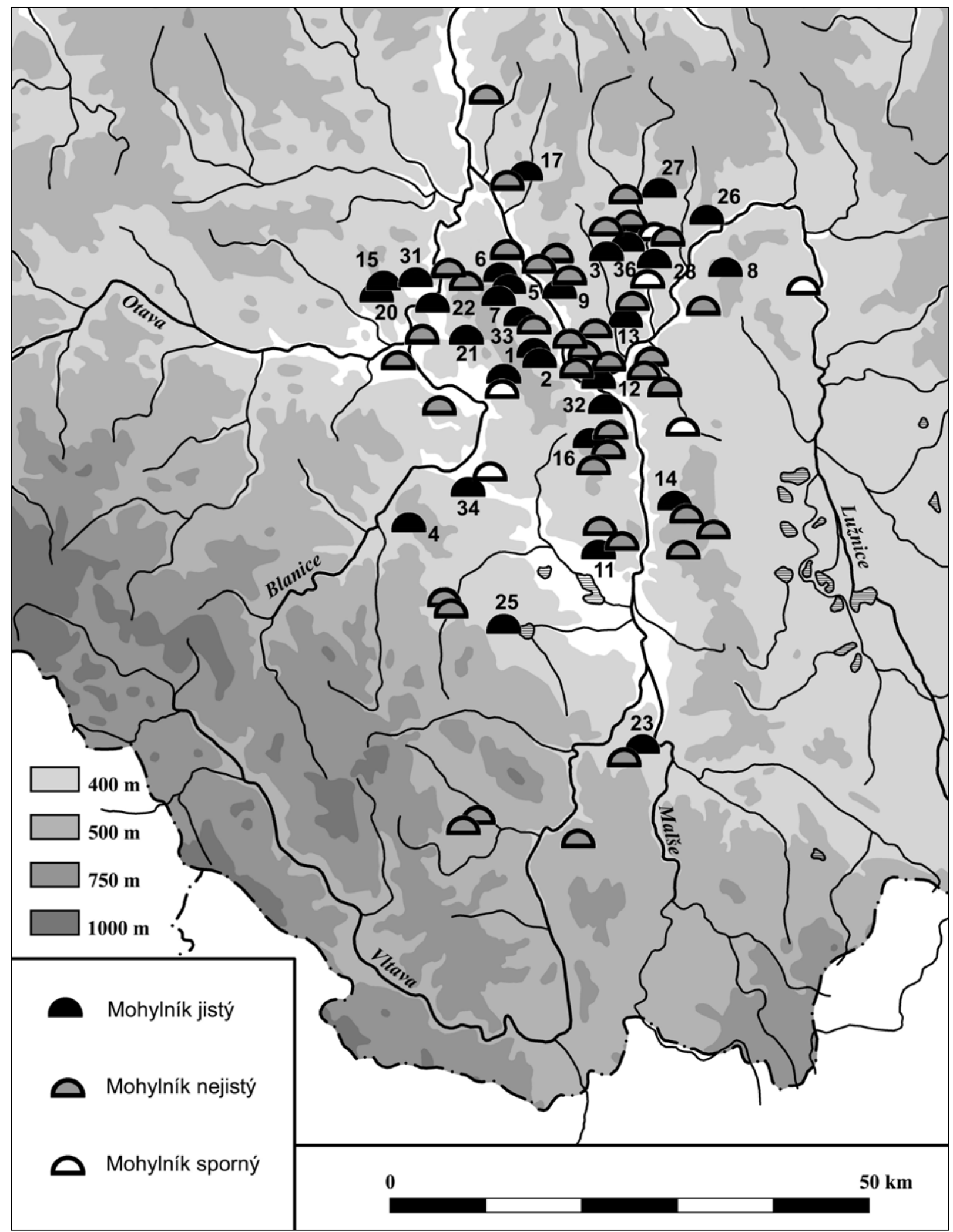

Obr. 2. Mohylová pohřebiště střední doby bronzové v jižních Čechách. Čísla u jistých pohřebišt odpovídají tabele 1 v textu (mapový podklad K. Vávra). 
hylník nebyl prozkoumán kompletně. Plánovité seskupování nebo strukturování nebylo pozorováno. Mezi lépe poznané patří lokalita ve Křtěnově, kde P. Braun prokopal 9 mohyl, bohužel bez detailnější publikace (Braun 1987, 95, 96). Moderně zhodnocené výzkumy šesti mohyl ve Vodňanech (Chvojka/Michálek 2013, obr. 2; Michálek 1997, 8, 9, obr. 6; 7) a dvou mohyl v Protivíně (Beneš/Michálek 2006, tab. IV) ukazují, že mohyly byly uspořádány blízko sebe a v některých případech se až dotýkaly.

Rovněž $\mathrm{v}$ následující střední době bronzové se v jižních Čechách setkáváme výlučně s mohylovými hroby, určitou výjimku představují jen patrně čtyři žárové hroby stupně BB1 uložené do destrukce hradby hradiště ve Vrcovicích (Beneš 1966; kriticky: Hlásek et al. 2015, 217-219). Počet mohyl na cca 90 lokalitách bývá odhadován na 1800 (Chvojka/Michálek 2013, 10-17; Tisucká 2008); podle provedené revize (tabela 1) však můžeme za bezpečně prokázaných pro střední dobu bronzovou považovat jen 73 mohyl z celkem 29 lokalit (obr. 2). Žádné z pohřebišt nebylo odkryto kompletně, i když některé lokality byly zkoumány plošně (napr. torzo nekropole v Písku-Bakalářích: Jiř́ík et al. 2012; pohřebiště v Oldřichově: Michálek 2017, 273-276). Základní nálezový fond z mohylových hrobů střední doby bronzové byl získán již v 19. a na počátku 20. století, a to především díky výzkumům J. L. Píče (1900). Ten nechal v letech 1888-1910 prozkoumat 136 mohyl na 21 lokalitách, z nichž zhruba 40 náleželo střední době bronzové (Chvojka/Michálek 2011, 66). Další výraznější výzkumy středobronzových mohyl proběhly až ve druhé polovině 20 . století, publikovány však byly (pokud vůbec) většinou až nedávno (např. Dobešice-Hrůbata: Beneš/Michálek 2012; Týn nad Vltavou: Chvojka/Michálek 2013, 14-17). Z novějších výzkumů lze jmenovat odkryv středobronzových mohyl u Radošovic (Chvojka/Michálek 2013, 12-14; Chvojka/Michálek/Zavřel 2011), Dražíče (Jiřík/Rytír 2004), dvě lokality u Dobešic (poloha Slavná hora: Choojka/Michálek 2005; 2013, 10-12; poloha Hrůbata: Krištuf/Rytír 2009) nebo již výše zmíněné výzkumy v Písku a Oldřichově. Nejnověji, v letech 2017-2018, pak byly odkryty tři mohyly v Plavu (Chvojkal Zavřel, v tisku). Několik mohylníků bylo sledováno také pomocí nedestruktivních metod, jako např. lokality v povodí ŕíčky Smutné na rozhraní Písecka a Táborska (Chvojka et al. 2011).

\section{KONTINUITA NEBO DISKONTINUITA} VYUŽÍVÁNÍ JIHOČESKÝCH MOHYLNÍKU゚?

Chronologické určení jihočeských starobronzových hrobů je možné pouze na základě typologického rozboru artefaktů nebo stratigrafických vztahů. Radiokarbonová data, spadající na přelom starší a střední doby bronzové (cca 1750-1530 př. $\mathrm{Kr}$.), pocházejí zatím pouze $\mathrm{z}$ pohřebiště $\mathrm{v}$ Dobešicích (Krištuf/Rytír 2009, 50, 51, tab. 1). Většina jihočeských hrobů starší doby bronzové patří do stupně BA2 (Hluboká nad Vltavou, Hosty, Těśínov, Vodňany), starší je pouze ne zcela jistý mohylový hrob v Maršově (Šálová/Chvojka/Menšík 2016, 90). V jižních Čechách dosud chybí, s výjimkou jedné mohyly v Dobešicích, bezpečně prokázané hroby z období BA2/BB1, ze stupně BB1 je pak jen několik vesměs nejistých hrobových souborů. $\mathrm{V}$ rámci mohyl střední doby bronzové jich většina náleží do stupňu BB2-BC. Tomu odpovídá i zatím jediné radiokarbonové datum $\mathrm{z}$ hrobu 3 ve zkoumané mohyle u Dobešic (Krištuf/Rytíř 2009, 50, tab. 1). Je však nutné upozornit, že bez exaktních dat je možné větší část souborů, zejména ze starších výzkumů, zařadit jen obecně do střední doby bronzové.

Většina $\mathrm{z}$ uvedených deseti prokázaných starobronzových pohřebišt vykazuje pohřbívání i v mladších pravěkých epochách, monokulturní jsou podle současného stavu poznání pouze dva mohylníky (Protivín: Beneš 1997, 194-197; Beneš/Michálek 2006, 5, tab. IV; V; Hájek 1954, 134, obr. 10: 1-4; Vodňany: Chvojka/Michálek 2013, 8, 9; Michálek 1996, 41). Mohylová pohřebiště s prokázanými pohřby ze starší i střední doby bronzové jsou v jižních Čechách jen čtyři. Podle aktuálního stavu poznání tak lze opakované (kontinuální?) využívání pohřebišt v obou sledovaných epochách považovat spíše za výjimečné. Zdůraznit ovšem musíme velmi omezený stav současných informací, daný nedostatečným stavem výzkumu jednotlivých lokalit. $\mathrm{Z}$ uvedených čtyř lokalit s prokázanými pohřby z obou epoch jsou dvě limitovány nedostatečnou dokumentací (Hosty: Beneš/Michálek/Zavřel 1999, 53; Paseky: Chvojka/Michálek 2011, 36-38) a jedna lokalita absencí podrobného zpracování a zveřejnění (Křtěnov: Braun 1987). Moderně zkoumaná a dobře dokumentovaná je tak jen lokalita v poloze Hrůbata u Dobešic, kde se v jižních Čechách poprvé podařilo prokázat vybudování mohyly na přelomu starší a střední doby bronzové a její navýšení v následující epoše střední doby bronzové (Krištuf/Rytíř 2009, 51).

\section{FORMÁLNÍ PODOBA A ROZMĚRY MOHYL}

Rozměry jihočeských starobronzových mohyl zř́dka dnes přesahují výšku $1 \mathrm{~m}$, půdorys násypu bývá kruhový nebo mírně oválný o průměru 5 až $10 \mathrm{~m}$. Výjimečná je $\mathrm{v}$ tomto př́ípadě jedna mohyla u Těšínova („Sýkovka“), která měla oválný tvar o rozměrech 26 x 16 m s výškou až $1,9 \mathrm{~m}$. O něco 
menší byla mohyla $\mathrm{z}$ polohy Selská o rozměrech 12 x 16 m (Dubský 1949, 71-77). Mohyly ze střední doby bronzové jsou rovněž kruhového až oválného půdorysu, dosahují průměru 5-20 m a výšek 0,2-2 m.

Vnitřní konstrukce jihočeských mohyl starší doby bronzové bývá rozmanitá, vždy se však objevují vnitřní kamenné prvky (Havlice 2001, 57, 58; Chvojkal Krištuf/Rytíř 2009, 89). Nejčastější je pravděpodobně centrální kamenné jádro kryjící pohřeb s hliněným pláštěm (např. Vodňany: Chvojka/Michálek 2013, 8, 9, obr. 2; 3; Michálek 1996, 41, obr. 2). Lze předpokládat, že většina mohyl ukrývala jediný komorový pohřeb v mohyle. Hrobové komory mohly být zahloubeny do podloží, mohly se však nacházet i v mohylovém náspu, na úrovni terénu na zemi (Protivín, mohyla I) nebo na ploše složené z kamenů (Nedabyle, mohyla I). S kamennými věnci se $\mathrm{v}$ této době setkáváme jen výjimečně (Těšínov-Selská: Dubský 1949, 85, obr. 8; Protivín - mohyla II: Beneš 1997, 194-200). Celokamenná konstrukce byla zjištěna pouze $\mathrm{u}$ dvou mohyl v Těšínově (Dubský 1949, 71-77) a u jedné v Hostech (Hájek 1954, 126-128).

Konstrukce mohyl ze střední doby bronzové tvořily většinou $1-2$ věnce, které bránily rozplavování hliněného násypu. Mohyly mají většinou kamenný plášt, který kryje jednu nebo i více hrobových komor čtvercového nebo oválného půdorysu. Ty obsahovaly kostrový nebo žárový pohřeb uložený většinou na úroveň terénu. Objevují se však i pohřby mimo tyto komory.

\section{POHŘEBNÍ RITUS JIHOČESKÝCH MOHYL STARŠÍ A STŘEDNÍ DOBY BRONZOVÉ}

Pohřební ritus jihočeské skupiny únětické kultury byl kostrový. Přes to, že se díky kyselé půdě lidské ostatky až na výjimky nedochovaly, můžeme díky hrobovým komorám (Těšínov, Vodňany) stanovit orientaci hrobů na severojižní, tedy stejnou jako v některých dalších podunajských skupinách. Žárové pohřby nebyly dosud $\mathrm{v}$ jižních Čechách bezpečně doloženy (Havlice 2001, 60), i když je nelze zcela vyloučit (Hájek 1954, 134). Teprve na počátku střední doby bronzové se v jižních Cechách objevují první jisté žárové hroby, jak naznačují výše uvedené čtyři hroby z hradiště u Vrcovic.

Ve střední době bronzové je obecně v Čechách konstatována biritualita pohřebního ritu (Jiráň ed. 2008, 122-125). Rovněž v jižních Čechách se setkáváme s oběma formami pohřbů, občas i v jedné mohyle (např. Dobešice-Kolomazná: Chvojka/Krištuf/Rytir 2009, 108; Dobešice-Hrůbata: Krištuf/Rytír 2009). Podle dnešního stavu poznání převažují v jižních Čechách hroby žárové, ovšem počet hrobů kostrových je evidentně silně redukován, jak ukazují i příklady z nejnověji zkoumaných mohyl v Plavu (Chvojka/Zavřel, v tisku). Mezi blíže neurčenými pohřby (tabela 1) tak mohou být většinově skryté právě nerozpoznané kostrové hroby.

Pohřby starší i střední doby bronzové většinou obsahují poměrně početné milodary. Jejich dnešní stav poznání ovšem může být zredukován úrovní terénních výzkumů u většiny starších výzkumů, absencí prosévání a plavení, stejně tak selekcí nálezů při výzkumech a jejich možnou redukcí v muzejních sbírkách. Mnoho drobných milodarů či předmětů $\mathrm{z}$ organických materiálů tak nepochybně nebylo objeveno. Vzhledem $\mathrm{k}$ uvedené prakticky totální redukci kosterních pozůstatků z jihočeských mohyl sledovaných epoch nejsou k dispozici žádná antropologická či archeogenetická data, která by přiblížila demografickou, sociální či genderovou skladbu pohřbených. Pouze podle charakteru pohřebních milodarů a př́padně podle stratigrafických vztahů mezi jednotlivými hroby lze usuzovat na zastoupení obou pohlaví v mohylách a patrně i různých věkových skupin, včetně dětí.

V násypech staro- i středobronzových mohyl se občas setkáváme s rozptýlenými zlomky keramiky (např. Čtrnáct 1973; Beneš 1997), případně i s dalšími artefakty. Ty se do pláště mohyl mohly dostat z blízkého sídlišš̌ (viz např. nejnověji dokumentovaný případ z Plava: Chvojka/Zavřel, v tisku), nebo mohlo jít o rituální praktiky během či po vlastním pohřebním obřadu.

\section{ZÁVĚR}

Pro jižní Čechy je ve starší a střední době bronzové typické pohřbívání zemřelých pod mohylové náspy. Ploché hroby nebyly v této oblasti doposud spolehlivě identifikovány. Během vývoje lze v pohřebním ritu pozorovat určité změny po stránce formální i prostorové. Rozsah osídlené plochy je ve sledovaném regionu $\mathrm{v}$ obou obdobích přibližně stejný a zaujímá centrální části jižních Čech, výraznější rozdíly ovšem můžeme vidět v hustotě a struktuře osídlení. Ve střední době bronzové se jádro osídlení posouvá do střední a severní části regionu na Bechyňsko, Písecko, Vltavotýnsko a Vodňansko. Naopak v jižní části jihočeského regionu oproti starší době bronzové dokladů lidských aktivit ubývá. Změnu lze pozorovat i v sídelní struktuře, kdy se ve střední době bronzové snížil počet výšinných lokalit a depotů kovových artefaktů a naopak přibylo pohřebních komponent (souhrnně viz Chvojka 2007).

Otázkou zůstává, jestli a do jaké míry je možné uvažovat o kontinuitě $\mathrm{v}$ pohřebním ritu. Jak bylo uvedeno výše, převážná většina mohylových po- 
hřebišt' s prokázanými pohřby ze sledované epochy poskytla doklady bud' pouze ze starší, nebo jen ze střední doby bronzové. Přesto alespoň několik zmíněných lokalit s pohřby z obou těchto období naznačuje poprvé v jižních Čechách existenci materiální paměti komunit (např. Neustupný 1997), kdy jsou areály aktivit správně identifikovány a kontinuálně využívány ke stejnému účelu. Teoreticky lze tak snad uvažovat o kontinuálním vývoji obyvatelstva, jen s částečnou a pozvolnou změnou symbolických systémů pod vlivy z okolních oblastí.

$Z$ topografického hlediska nelze na základě současných poznatků identifikovat jasné rozdíly $\mathrm{v}$ umístění mohylníků $\mathrm{v}$ prostoru a čase. Většinou se nacházejí na plochých nebo mírně se svažujících terasách nebo vyvýšeninách, ne př́liš vzdálených od vodních toků. Absence blízkého časově shodného osídlení v některých mikroregionech je s největší pravděpodobností způsobena stavem výzkumu. V obou sledovaných obdobích lze předpokládat $\mathrm{v}$ okolí pohřebišt existenci rovinných sídlišt', mnohdy ovšem zatím neobjevených. Odhad počtu tehdejších obyvatel jižních Čech na základě srovnání počtu pohřebišt’ a rovinných sídliš̌t starší a střední doby bronzové (srov. Chvojka 2011) naznačuje, že ukládání zemřelých pod mohyly nemuselo být jediným druhem pohřbu těchto komunit. Další způsob zacházení s ostatky zemřelých není ovšem $z$ archeologického hlediska v tuto chvíli zachytitelný.

\section{LITERATURA}

Beneš 1966 - A. Beneš: Vrcovice. Bulletin záchranného oddělení 3, 1966, 84-87.

Beneš 1997 - A. Beneš: Die Streuscherben in süd- und westböhmischen Grabhügeln. In: J. Michálek/K. Schmotz/ M. Zápotocká (Hrsg.): Archäologische Arbeitsgemeinschaft Ostbayern/West- und Südböhmen. 6. Treffen 12. bis 15. Juni 1996 in Hluboká nad Vltavou. Espelkamp 1997, 194-200.

Beneš/Michálek 2006 - A. Beneš/J. Michálek: Památník města Protivína. Pobočka Prácheňského muzea v Písku. Katalog archeologické sbírky. Zprávy České archeologické společnosti. Supplément 61. Praha 2006.

Beneš/Michálek 2012 - A. Beneš/J. Michálek: Výzkum mohyly ze střední doby bronzové v polní trati Hrůbata u Dobešic (okr. Písek) v roce 1964. Archeologie západních Čech 3, 2012, 92-101.

Beneš/Michálek/Zavřel 1999 - A. Beneš/J. Michálek/P. Zavřel: Archeologické nemovité památky v okresu České Budějovice, díly I-II. Praha 1999.

Braun 1987 - P. Braun: Vorgriffsausgrabungen auf dem Atomkraftwerk Temelín, Südböhmen. In: E. Černá (Hrsg.): Archäologische Rettungstätigkeit in den Braunkohlengebieten und die Problematik der Siedlungs-geschichtlichen Forschung. Prag 1987, 251-253.

Čtrnáct 1973 - V. Čtrnáct: Zásypová keramika ze středobronzových mohyl na Plzeňsku. Výzkumy $v$ Čechách 1970, 1973, 184-211.

Dubský 1949 - B. Dubský: Pravěk jižních Čech. Blatná 1949.

Fröhlich/Michálek 1978 - J. Fröhlich/J. Michálek: Archeologické nemovité památky okresu Písek. Zprávy Československé společnosti archeologické 20, 1978, 87-131.

Hájek 1954 - L. Hájek: Jižní Čechy ve starší době bronzové. Památky archeologické 45, 1954, 115-192.

Havlice 2001 - J. Havlice: Pohřební ritus starší doby bronzové v jižních Čechách. Archeologické výzkumy v jižních Čechách 14, 2001, 57-64.

Hlásek et al. 2015 - D. Hlásek/O. Chvojka/T. Šálková/ J. Fröhlich/P. Houfková/P. Kovačiková/A. Majer/ P. Menšík/J. Michálek/P. Netolický/J. Novák/J. Pavelka/ J. Petřík/D. Sosna: Vrcovice. Hradiště z počátku střední doby bronzové. Archeologické výzkumy v jižních Čechách. Supplementum 10. České Budějovice - Plzeň 2015.

Chvojka 2007 - O. Chvojka: Současný stav poznání doby bronzové v jižních Čechách. In: O. Chvojka/R. Krajíc (ed.): Archeologie na pomezí. Sborník příspěvků ze semináře. České Budějovice, 8. 11. 2007. Archeologické výzkumy v jižních Čechách. Supplementum 4. Ceské Budějovice 2007, 29-55.

Chvojka 2011 - O. Chvojka: Rovinná sídliště doby bronzové v hornodunajském kulturním okruhu. Habilitační práce. Filozofická fakulta Masarykovy Univerzity. Brno 2011. Nepublikované.

Chvojka et al. 2011 - O. Chvojka/J. Beneš/J. Fröhlich/J. John/ J. Michálek/T. Šálková/A. Bernardová/P. Houfková/ R. Křivánek/A. Majer/J. Novák/K. Nováková/E. Talarovičová: Osídlení z doby bronzové v povodí říčky Smutné v jižních Čechách. Archeologické výzkumy v jižních Čechách. Supplementum 8. Ceské Budějovice 2011.

Chvojka/Krištuf/Rytír 2009 - O. Chvojka/P. Krištuf/L. Rytír: Mohylová pohřebiště na okrese Písek. 1. Díl. Cíle, současný stav, poznání a metoda sběru dat. Archeologické výzkumy v jižních Čechách. Supplementum 6. České Budějovice 2009.

Chvojka/Menšík, v tisku-O. Chvojka/P. Menšík: Frühbronzezeitliche Hügelgrabbestattungen in Südböhmen. Fines Transire 29, v tisku.

Chvojka/Michálek 2005 - O. Chvojka/J. Michálek: Výzkum mohyly ze střední doby bronzové u Dobešic. In: $A r-$ cheologické výzkumy v Čechách 2004. Sborník referátů z informačního kolokvia. Zprávy České archeologické společnosti. Supplément 60. Praha 2005, 23.

Chvojka/Michálek 2011 - O. Chvojka/J. Michálek: Výzkumy Josefa Ladislava Píče na mohylových pohřebištích doby bronzové a halštatské v jižních Čechách. Fontes Archaeologici Pragenses 35. Praha 2011.

Chvojka/Michálek 2013 - O. Chvojka/J. Michálek: Nové poznatky $\mathrm{k}$ mohylovým pohřbům doby bronzové v jižních Čechách. Archeologie západních Čech 5, 2013, 7-22. Chvojka/Michálek/Zavřel 2011 - O. Chvojka/J. Michálek/ P. Zavřel: Výzkum mohyl z doby bronzové a halštatské 
u Radošovic, okres České Budějovice. Archeologické výzkumy v jižních Čechách 24, 2011, 41-77.

Chvojka/Zavřel, v tisku-O. Chvojka/P. Zavřel: Alt bekannt, neu untersucht. Ergebnisse der modernen archäologischen Forschung von drei vorgeschichtlichen Grabhügeln bei Plav, Kr. Ceské Budějovice. Fines Transire 29, v tisku.

Jiráň ed. 2008 - L. Jiráň (ed.): Archeologie pravěkých Čech 5. Doba bronzová. Praha 2008.

Jiř́k et al. 2012 - J. Jiř́ík/M. Pták/T. Šálková/M. Tisucká: Pohřbívání v Písku na Bakalárích. Acta archaeologica Opavensia 4, 2012, 113-118.

Jiř́k/Rytír 2004 - J. Jiřík/L. Rytíř: Revizní výzkum narušené mohyly ze střední doby bronzové v Dražíči, okr. Písek. Archeologické výzkumy v jižních Čechách 17, 2004, 103-120.

Krištuf/Rytǐr 2009 - P. Krištuf/L. Rytír: Radiokarbonová data z mohylového pohřebiště "Na Hrůbatech“, k. ú. Dobešice (okr. Písek). Archeologické výzkumy v jižních Čechách 22, 2009, 49-60.

Menšík/Krištuf/Chvojka 2010 - P. Menšík/P. Krištuf/O. Chvojka: Mohylová pohřebiště na okrese Tábor. Plzeň 2010.

Michálek 1996 - J. Michálek: Neue früh, mittel- und jungbronzezeitliche Funde und Befunde bei Vodňany, Kreis Strakonice, im Jahre 1994. In: K. Schmotz/M. Zápotocká (Hrsg.): Archaölogische Arbeitsgemeinschaft Ostbayern/ West- und Südböhmen. 5. Treffen 21. bis 24. Juni 1995 in Sulzbach-Rosenberg, Resümees der Vorträge. Espelkamp 1996, 40-48.

Michálek 1997 - J. Michálek: Vodňany a okolí v pravěku a na počátku dějin. In: Vodňany a Vodňansko 4. Sborník

Rukopis přijat 25. 5. 2020

Translated by Petr Menšík

doc. Mgr. Ondřej Chvojka, Ph.D.

Jihočeská univerzita v Českých Budějovicích

Archeologický ústav

Branišovská 31a

CZ - 37005 České Budějovice

ochvojka@ff.jcu.cz historických prací k dějinám města Vodňan vydaný u př́ležitosti oslav Roku Vodňan (1996-1997). Vodňany 1997, 2-37.

Michálek 2017 - J. Michálek: Mohylová pohřebiště doby halštatské (Ha C-D) a časně laténské ( LT A) v jižních Čechách I.-III. Praha 2017.

Michálek/Fröhlich 1979 - J. Michálek/J. Fröhlich: Archeologické nemovité památky v okrese Strakonice. České Budějovice - Strakonice 1979.

Michálek/Fröhlich 1987 - J. Michálek/J. Fröhlich: Archeologické nemovité památky v okrese Prachatice. Prachatice 1987.

Michálek/Zavřel 1996 - J. Michálek/P. Zavřel: Archeologické nemovité památky okresu Český Krumlov. České Budějovice - Český Krumlov 1996.

Militký 1998 - J. Militký: Frühbronzezeitliche Gräber in Südböhmen. Zum Stand der Forschung. In: J. Michálek/ K. Schmotz/M. Zápotocká (Hrsg.): Archäologische Arbeitsgemeinschaft Ostbayern/West- und Südböhmen. 7. Treffen in Landau an der Isar. Rahden/Westf. 1998, 88-101.

Neustupný 1997 - E. Neustupný: Uvědomování minulosti. Archeologické rozhledy 49, 1997, 217-230.

Píč 1900 - J. L. Píč: Starožitnosti země České, díl I, sv. 2. Pokolení kamenných mohyl. Praha 1900.

Šálová/Chvojka/Menšík 2016 - M. Šálová/O. Chvojka/P. Menšík: Pravěká mohyla u Maršova (okr. Tábor). Příspěvek ke starší době bronzové na Táborsku. Archeologické výzkumy v jižních Čechách 29, 2016, 87-97.

Tisucká 2008 - M. Tisucká: Př́spěvky ke střední době bronzové $v$ jižních Čechách. Zprávy Ceské archeologické společnosti. Supplementum 70. Praha 2008.
PhDr. Petr Menšík, Ph.D.

Západočeská univerzita v Plzni

FF Katedra archeologie

Sedláčkova 15

CZ - 30614 Plzeň

pmensik@kar.zcu.cz 


\title{
Early and Middle Bronze Age Burial Mounds in Southern Bohemia Continuity or Discontinuity of Using Burial Sites?
}

\author{
Ondřej Chvojka - Petr Menšík
}

\begin{abstract}
SUMMARY
Burying the dead in burial mounds represents a typical burial rite in Early and Middle Bronze Age in southern Bohemia, whilst no flat graves have been conclusively discovered yet. During its development, certain formal and spatial changes can be found within the burial rite. The extent of settled area is approximately the same in both eras, occupying the central part of southern Bohemia; however, significant differences can be seen in settlement density and structure. Regarding the settlement structure, the number of hill-top settlements and metal hoards plummeted significantly, while the number of burial components roses. The continuity of burial rite remains unsolved, as

most of the burial mounds only contained burials from the Early or Middle Bronze Age. Leastwise some burial grounds indicate further burying, though; possibly an evidence of continuous population development. From the topographical point of view, no clear distinction can be identified from the location of burial mounds in space and time based on current state of knowledge. The estimate of the number of then inhabitants of southern Bohemia based on the comparison of burial grounds and flat settlements of the Early and Middle Bronze Age suggests that tumulus burials did not need to be the only kind of burial rite of these communities.
\end{abstract}

Fig. 1. Burial mound cemeteries of the Early Bronze Age in southern Bohemia. The numbers for certain cemeteries correspond to Table 1 in the text (map by K. Vávra).

Fig. 2. Burial mound cemeteries of the Middle Bronze Age in southern Bohemia. The numbers for certain cemeteries correspond to Table 1 in the text (map by K. Vávra).

Table 1. The overview of southern Bohemian burial mounds with verified Early and Middle Bronze
Age graves; burial mounds containing unpublished burials and only with preserved artefacts are not included (used sources: Dubský 1949; Hájek 1954; Chvojka/Krištuf/Rytír 2009; Chvojka/Michálek 2011; Menšík/ Krištuf/Chvojka 2010; Michálek 2017; Militký 1998; Píč 1900; Tisucká 2008 and further authors' unpublished sources). ${ }^{*}$ The minimum amount of verified burial mounds within the site regardless their dating, state of knowledge, etc. 
